\title{
SS-064 測定と意思決定の公理的アプローチ
}

\author{
企画代表者、話題提供者、司会者: 竹村 和久 (早稲田大学) \\ 話題提供者: 吉野 諒三 (統計数理研究所) \\ 話題提供者:松下裕\# (金沢工業大学) \\ 指定討論者 : 坂上 貴之 (慶應義塾大学) \\ 指定討論者: 椎名 乾平 (早稲田大学)
}

測定と意思決定の研究は、定性的研究、定量的研究、観察、実験など理学研究のなかでほとんど常にな されている。これらの測定や意思決定の問題を集合論などの現代数学の概念をもとにして公理的に体系 化してゆく理論に，公理的な測定論や公理的意思決定論がある。これらは、本来は心理学者のLuce,D., Krantz,D., Tversky,A. らによって盛んに研究されて、心理学の理論の中に取り込まれているが、計量 心理学との考え方が異なる部分もあり、それほど普及していない。しかし、近年になって盛んとなって きた公理的方法を用いる経済学やゲーム理論や社会的選択理論などの諸研究との統合を考えると、心理 学研究にとっても検討しないといけない課題になっていると思われる。本シンポジウムでは、測定や意 思決定の公理的アプローチの研究を話題提供者にわかりやすくしてもらい、指定討論者によって、この アプローチの将来性や問題点などについて議論を行う予定である。 